\title{
Wydatki wiejskich i miejskich gospodarstw domowych na dobra i usługi konsumpcyjne a ich ceny
}

\section{Wstęp}

Wielkość i struktura wydatków konsumpcyjnych gospodarstwa domowych uzależniona jest od dochodów, cen dóbr oraz indywidualnych preferencji. Opracowanie przedstawia kształtowanie się wydatków na poszczególne grupy towarów i usług konsumpcyjnych w gospodarstwach domowych wiejskich i miejskich na tle zmian cen w poszczególnych grupach wydatków konsumpcyjnych.

W opracowaniu wykorzystano dane Głównego Urzędu Statystycznego zawarte w badaniach: „Budżety gospodarstw domowych” oraz „Ceny w gospodarce narodowej" za rok 2006 i 2014, co umożliwiło pokazanie zmian, które zaszły w tym czasie. Jako bazowy przyjęto rok 2006, gdyż w publikacji GUS za rok 2005 nie uwzględniono wyszczególnienia wydatków na towary i usługi konsumpcyjne według miejsca zamieszkania.

Celem opracowania było zbadanie kształtowania się zmian wartości i struktury wydatków na towary i usługi konsumpcyjne w wiejskich i miejskich gospodarstwach domowych na tle zmian cen poszczególnych dóbr i usług konsumpcyjnych.

\section{Uwarunkowania wielkości i struktury wydatków konsumpcyjnych gospodarstw domowych}

Wydatki na towary i usługi konsumpcyjne są to kwoty przeznaczone na zaspokojenie różnorodnych potrzeb gospodarstwa domowego i obejmują wydatki na: żywność i napoje bezalkoholowe, napoje alkoholowe, wyroby tytoniowe 


\section{2}

i narkotyki, odzież i obuwie, użytkowanie mieszkania i nośniki energii, wyposażenie mieszkania i prowadzenie gospodarstwa domowego, zdrowie, transport, łączność, rekreację i kulturę, edukację, restauracje i hotele, pozostałe towary i usługi oraz kieszonkowe, które jest pozycją uwzględniającą kwoty przeznaczane na konsumpcję, ale wobec których nie można określić na zakup jakich artykułów i usług zostało przeznaczone [GUS 2007].

Wysokość wydatków konsumpcyjnych gospodarstw domowych zależy od wielu czynników, które zwykle są grupowe według obszarów ich występowania. W tym ujęciu wyróżnia się najczęściej czynniki o charakterze psychologicznym (motywy działania, osobowość, zwyczaje, styl życia), ekonomicznym (dochody i sytuacja materialna podmiotu podejmującego decyzję, ceny dóbr), społeczno-kulturowym (wykształcenie, zawód, elementy kultury) oraz demograficznym (wiek, płeć oraz miejsce zamieszkania) [Podogrodzka 2011].

Zgodnie z neoklasyczną teorią wyboru konsumenta popyt konsumpcyjny jest determinowany przez trzy podstawowe czynniki: dochód, ceny i preferencje. Badania Gałązi pokazują, że na preferencje konsumentów w istotny sposób wpływają takie cechy gospodarstw domowych, jak: liczba osób w gospodarstwie domowym, przynależność do grupy społeczno-zawodowej, typ biologiczny czy też miejsce zamieszkania [Gałąka 2012].

Badania dotyczące zmiany wydatków na poszczególne kategorie dóbr i usług konsumpcyjnych pokazują, że wraz ze zwiększaniem się dochodów na osobę rosną wydatki zarówno wiejskich, jak i miejskich gospodarstw domowych na: łączność, wyposażenie mieszkania i prowadzenie gospodarstwa domowego oraz żywność i napoje bezalkoholowe [Utzig 2015b]. Jednocześnie wraz ze wzrostem dochodów zwiększają się zakupy usług związanych z zagospodarowaniem czasu wolnego, $\mathrm{z}$ inwestowaniem $\mathrm{w}$ człowieka oraz komunikowaniem się $\mathrm{z}$ otoczeniem i przemieszczaniem się [Radziukiewicz 2012].

$\mathrm{Z}$ kolei $\mathrm{w}$ warunkach pogorszenia się koniunktury gospodarczej, a co za tym idzie obniżenia dochodów, przybierają na sile takie trendy w konsumpcji, jak świadoma konsumpcja (etyczna, odpowiedzialna społecznie i ekologicznie), konsumpcja współpracująca (pożyczanie, wymiana, umowy barterowe w opozycji do własności), ruch zorientowany na racjonalizację gospodarowania zasobami i zmniejszenie marnotrawstwa produktów (freeganizm), wpływ mediów społecznościowych na kształtowanie potrzeb (social media), porównywanie cen i wyszukiwanie okazji (smart shopping) oraz zaspokajanie w domach zamiast $\mathrm{w}$ instytucjach publicznych potrzeb kulturalnych, edukacyjnych, rekreacyjnych (domocentryzm) [Zalega 2013]. Zwiększenie świadomości konsumentów ma szczególne znaczenie przy uwzględnieniu faktu, że każdego roku około 1/3 żywności produkowanej globalnie jest tracona lub marnowana, przy czym marno- 
trawstwo żywności jest głównie problemem krajów wysokorozwiniętych [Gruda i Rembisz 2013, s. 87].

Wiejskie i miejskie gospodarstwa domowe różnią się pod względem sposobów pozyskiwania i rozdysponowywania dochodów. W wiejskich gospodarstwach domowych przenikają się funkcje produkcyjne i konsumpcyjne, dlatego w strukturze ich rozchodów istotne miejsce zajmują rozchody na bieżącą produkcję rolniczą i inwestycje oraz obciążenia finansowe, wśród których duże znaczenie mają podatek rolny, składki ubezpieczeniowe czy opłaty melioracyjne [Gutkowska i Piekut 2014].

Zbadanie struktury wydatków konsumpcyjnych gospodarstw domowych pozwala na przyjrzenie się podobieństwom i różnicom w poziomie życia poszczególnych gospodarstwa domowych, służy też do oceny poziomu życia całego społeczeństwa [Zalega 2011, s. 479]. Udział wydatków na zaspokojenie najpilniejszych potrzeb (tj. wydatków na żywność i napoje bezalkoholowe oraz na użytkowanie mieszkania i nośniki energii) w budżetach gospodarstw domowych jest wskaźnikiem służącym od oceny sytuacji finansowej. Większy udział wydatków podstawowych $\mathrm{w}$ dochodach rozporządzalnych gospodarstw domowych utrudnia zaspokojenie potrzeb ponadpodstawowych (m.in. dotyczących zagospodarowania czasu wolnego, edukacji), wpływając na obniżenie poziomu ich życia [Kozera, Stanisławska i Wysocki 2014, s. 97]. Badania Piekut pokazuja, że w gospodarstwach domowych zlokalizowanych w Europie Zachodniej i Północnej, a więc charakteryzujących się wyższymi dochodami, obserwowana jest korzystniejsza struktura konsumpcji, o mniejszym udziale wydatków na dobra podstawowe (zazwyczaj poniżej 40\%, wyjątkiem jest Dania, o sięgającym 30\% udziale wydatków na utrzymanie mieszkania w wydatkach konsumpcyjnych ogółem), a większym na usługi. Jednocześnie w gospodarstwach domowych w krajach bloku wschodniego znaczącą część (41-44\%) budżetów domowych pochłaniają wydatki na zaspokojenie potrzeb żywnościowych oraz związanych z utrzymaniem mieszkania [Piekut 2013, s. 30-31].

\section{Struktura wydatków wiejskich i miejskich gospodarstw domowych na towary i usługi konsumpcyjne a ich ceny}

Przeciętne dochody do dyspozycji na osobę w gospodarstwie domowym wiejskim były niższe niż w gospodarstwie domowym miejskim (w 2006 roku o $29 \%$ a w 2014 roku o $20 \%$ ). Relatywnie sytuacja dochodowa gospodarstw domowych wiejskich uległa jednak w tym okresie poprawie. Od 2006 roku do 2014 roku w ujęciu nominalnym dochody do dyspozycji w gospodarstwach do- 
mowych wiejskich wzrosły o $61 \%$, podczas gdy w gospodarstwach domowych miejskich o $43 \%$, w ujęciu realnym wzrost ten wynosił $30 \% \mathrm{w}$ gospodarstwach domowych wiejskich oraz $15 \% \mathrm{w}$ gospodarstwach domowych miejskich [GUS 2007; GUS 2015].

W tabeli 1 przedstawiono przeciętne wydatki na poszczególne kategorie towarów i usług konsumpcyjnych na osobę w gospodarstwach domowych wiejskim i miejskim w roku 2006 oraz 2014 oraz ich stopę wzrostu w badanym okresie w ujęciu nominalnym.

W latach 2006-2014 łączne wydatki na towary i usług konsumpcyjne zwiększyły się w ujęciu nominalnym o 44,7\% w gospodarstwach domowych miejskich oraz o $46 \%$ w gospodarstwach domowych wiejskich. Zarówno w gospodarstwach

\section{Tabela 1}

Przeciętne miesięczne wydatki na poszczególne kategorie towarów i usług konsumpcyjnych na osobę w gospodarstwach domowych wiejskim i miejskim w cenach bieżących oraz ich stopa wzrostu w latach 2006-2014

\begin{tabular}{|l|c|c|c|c|c|c|}
\hline \multirow{2}{*}{ Wydatki/wyszczególnienie } & \multicolumn{3}{|c|}{$\begin{array}{c}\text { Gospodarstwa domowe } \\
\text { wiejskie }\end{array}$} & \multicolumn{3}{|c|}{$\begin{array}{c}\text { Gospodarstwa domowe } \\
\text { miejskie }\end{array}$} \\
\cline { 2 - 7 } & $\begin{array}{c}2006 \\
\text { [zł] }\end{array}$ & $\begin{array}{c}2014 \\
\text { [zł] }\end{array}$ & $\begin{array}{c}\text { Stopa } \\
\text { Wzrostu } \\
\begin{array}{c}\text { 2006-2014 } \\
\text { [zł] }\end{array}\end{array}$ & $\begin{array}{c}2006 \\
\text { [zł] }\end{array}$ & $\begin{array}{c}2014 \\
\text { [zł] }\end{array}$ & $\begin{array}{c}\text { Stopa } \\
\text { Wzrostu } \\
2006-2014 \\
\text { [zł] }\end{array}$ \\
\hline Żywność i napoje bezalkoholowe & 192,59 & 243,55 & 26,5 & 208,03 & 276,06 & 32,7 \\
\hline $\begin{array}{l}\text { Napoje alkoholowe, } \\
\text { wyroby tytoniowe i narkotyki }\end{array}$ & 16,25 & 21,61 & 33,0 & 22,32 & 30,85 & 38,2 \\
\hline Odzież i obuwie & 31,45 & 46,52 & 47,9 & 45,62 & 65,03 & 42,5 \\
\hline $\begin{array}{l}\text { Użytkowanie mieszkania i nośniki } \\
\text { energii }\end{array}$ & 112,09 & 167,25 & 49,2 & 168,64 & 248,55 & 47,4 \\
\hline $\begin{array}{l}\text { Wyposażenie mieszkania } \\
\text { i prowadzenie gospodarstwa } \\
\text { domowego }\end{array}$ & 30,84 & 43,47 & 41,0 & 42,39 & 58,73 & 38,5 \\
\hline Zdrowie & 28,17 & 40,95 & 45,4 & 41,80 & 62,31 & 49,1 \\
\hline Transport & 58,61 & 91,45 & 56,0 & 69,46 & 103,83 & 49,5 \\
\hline Łącznośćn & 28,17 & 42,20 & 49,8 & 44,70 & 61,87 & 38,4 \\
\hline Rekreacja i kultura & 30,74 & 48,53 & 57,9 & 67,19 & 84,02 & 25,0 \\
\hline Edukacja & 5,67 & 5,89 & 3,9 & 13,41 & 15,9 & 18,6 \\
\hline Restauracje i hotele & 7,36 & 25,84 & 251,1 & 19,16 & 57,47 & 199,9 \\
\hline Pozostałe towary i usługi & 27,33 & 45,22 & 65,5 & 44,62 & 73,63 & 65,0 \\
\hline Kieszonkowe & 7,94 & 20,06 & 152,6 & 9,50 & 14,96 & 57,5 \\
\hline
\end{tabular}

Źródło: Budżety gospodarstw domowych w 2006 r., Główny Urząd Statystyczny, Warszawa 2007; Budżety Gospodarstw Domowych w 2014 r., Główny Urząd Statystyczny, Warszawa 2015. 
domowych wiejskich, jak i miejskich znacznie zwiększyły się wydatki na restauracje i hotele, o około $200 \% \mathrm{w}$ gospodarstwach domowych miejskich i o $251 \%$ w gospodarstwach domowych wiejskich. W 2014 roku nadal jednak przeciętne wydatki na restauracje i hotele przypadające na osobę w gospodarstwach domowych miejskich były ponad dwukrotnie wyższe niż w gospodarstwach domowych wiejskich. W okresie od 2006 do 2014 roku zarówno w gospodarstwach domowych wiejskich, jak i w miejskich w najmniejszym stopniu wzrosły wydatki na edukację (o niespełna 4\% w gospodarstwach domowych wiejskich, oraz o niespełna 19\% w gospodarstwach domowych miejskich).

Zarówno w roku 2006, jak i w 2014 przeciętne wydatki na prawie wszystkie kategorie towarów i usług konsumpcyjnych były wyższe w gospodarstwach domowych miejskich niż w wiejskich (poza wydatkami na kieszonkowe w 2014 roku).

Zarówno w gospodarstwach domowych wiejskich, jak i w miejskich pozycjami najbardziej obciążającymi budżety gospodarstw domowych były wydatki na żywność i napoje bezalkoholowe oraz wydatki na użytkowanie mieszkania i nośniki energii. Szczegółowa struktura wydatków konsumpcyjnych wiejskich i miejskich gospodarstw domowych została przedstawiona w tabeli 2.

Udział wydatków na żywność i napoje bezalkoholowe w wydatkach na towary i usługi konsumpcyjne ogółem zmniejszył się w badanym okresie w wiej-

\section{Tabela 2}

Struktura wydatków konsumpcyjnych wiejskich i miejskich gospodarstw domowych [\%]

\begin{tabular}{|l|c|c|c|c|}
\hline \multirow{2}{*}{ Wydatki/wyszczególnienie } & \multicolumn{2}{|c|}{$\begin{array}{c}\text { Gospodarstwa } \\
\text { domowe wiejskie }\end{array}$} & \multicolumn{2}{c|}{$\begin{array}{c}\text { Gospodarstwa } \\
\text { domowe miejskie }\end{array}$} \\
\cline { 2 - 5 } & 2006 & 2014 & 2006 & 2014 \\
\hline Żywność i napoje bezalkoholowe & 33,37 & 28,91 & 26,11 & 23,94 \\
\hline Napoje alkoholowe, wyroby tytoniowe i narkotyki & 2,82 & 2,56 & 2,80 & 2,68 \\
\hline Odzież i obuwie & 5,45 & 5,52 & 5,73 & 5,64 \\
\hline Użytkowanie mieszkania i nośniki energii & 19,42 & 19,85 & 21,16 & 21,55 \\
\hline $\begin{array}{l}\text { Wyposażenie mieszkania i prowadzenie gospo- } \\
\text { darstwa domowego }\end{array}$ & 5,34 & 5,16 & 5,32 & 5,09 \\
\hline Zdrowie & 4,88 & 4,86 & 5,25 & 5,40 \\
\hline Transport & 10,15 & 10,85 & 8,72 & 9,00 \\
\hline Łaczność & 4,88 & 5,01 & 5,61 & 5,37 \\
\hline Rekreacja i kultura & 5,33 & 5,76 & 8,43 & 7,29 \\
\hline Edukacja & 0,98 & 0,70 & 1,68 & 1,38 \\
\hline Restauracje i hotele & 1,28 & 3,07 & 2,40 & 4,98 \\
\hline Pozostałe towary i usługi & 4,73 & 5,37 & 5,60 & 6,38 \\
\hline Kieszonkowe & 1,38 & 2,38 & 1,19 & 1,30 \\
\hline
\end{tabular}

Źródło: Jak w tabeli 1. 
skich i w miejskich gospodarstwach domowych, przy czym nadal był wyższy w gospodarstwach domowych na wsi. Udział wydatków na użytkowanie mieszkania i nośniki energii był wyższy w gospodarstwach domowych miejskich niż w wiejskich i zwiększał się w badanym okresie. Zmniejszenie się udziału wydatków na żywność i napoje bezalkoholowe jest zjawiskiem pozytywnym, świadczącym o bogaceniu się społeczeństwa. Podobnie pozytywnie należy interpretować zwiększenie się udziału wydatków na restauracje i hotele, które wystąiło zarówno w wiejskich, jak i miejskich gospodarstwach domowych. Jednocześnie nieznaczny wzrost udziału wydatków na użytkowanie mieszkania i nośniki energii jest zjawiskiem o charakterze negatywnym.

Pod względem udziału wydatków na żywność i napoje bezalkoholowe gospodarstwa domowe zamieszkałe na wsi były bliższe gospodarstwom domowym pracowników na stanowiskach robotniczych, rolników, emerytów i rencistów, a różniły się najmocniej od gospodarstw domowych pracujących na własny rachunek oraz pracowników na stanowiskach nierobotniczych [Utzig 2015a].

Badając wielkość i strukturę wydatków konsumpcyjnych gospodarstw domowych, należy zwrócić uwagę na fakt, że ceny poszczególnych dóbr konsumpcyjnych nie zmieniały się równolegle. $\mathrm{W}$ tabeli 3 przedstawiono indeks wzrostu cen poszczególnych towarów i usług konsumpcyjnych między rokiem 2006 a 2014 .

\section{Tabela 3}

Indeks wzrostu cen poszczególnych towarów i usług konsumpcyjnych w okresie 2006$-2014$

\begin{tabular}{|l|c|}
\hline Wydatki/wyszczególnienie & $\begin{array}{c}\text { Indeks wzrostu cen } \\
2006-2014\end{array}$ \\
\hline Żywność i napoje bezalkoholowe & 1,322 \\
\hline Napoje alkoholowe, wyroby tytoniowe i narkotyki & 1,467 \\
\hline Odzież i obuwie & 0,657 \\
\hline Użytkowanie mieszkania i nośniki energii & 1,486 \\
\hline Wyposażenie mieszkania i prowadzenie gospodarstwa domowego & 1,122 \\
\hline Zdrowie & 1,233 \\
\hline Transport & 1,206 \\
\hline Łączność & 0,897 \\
\hline Rekreacja i kultura & 1,073 \\
\hline Edukacja & 1,155 \\
\hline Restauracje i hotele & 1,325 \\
\hline Pozostałe towary i usługi & 1,137 \\
\hline
\end{tabular}

Źródło: Opracowanie własne na podstawie: Ceny w gospodarce narodowej w $2012 r$, Główny Urząd Statystyczny w Opolu, Warszawa 2013; Ceny w gospodarce narodowej w 2014 r., Główny Urząd Statystyczny w Opolu, Warszawa 2015. 
Pomiędzy rokiem 2006 a 2014 najsilniej wzrosły ceny wyposażenia mieszkania i nośników energii (o 48,6\%) oraz napojów alkoholowych, wyrobów tytoniowych i narkotyków (o 46,7\%). Znacznie wzrosły ceny w kategorii restauracje i hotele (o 32,5\%) oraz ceny żywności i napojów bezalkoholowych $(32,2 \%)$. W badanym okresie ceny pewnych grup wydatków na towary i usługi konsumpcyjne uległy zmniejszeniu. Największy spadek cen odnotowano w odniesieniu do kategorii odzież i obuwie (o 34,3\%) oraz w kategorii łączność (o 10,3\%).

Od 2006 do 2014 roku ceny towarów i usług konsumpcyjnych wzrosły o 23,8\% [Obliczenia własne na podstawie danych GUS], zatem można stwierdzić, że w badanym okresie sytuacja gospodarstw domowych uległa pogorszeniu ze względu na to, że w tym czasie relatywnie podrożały wydatki na towary i usługi najsilniej obciążające budżety gospodarstw domowych, czyli wydatki na żywność i napoje bezalkoholowe oraz użytkowanie mieszkania i nośniki energii.

Porównanie zmian wysokości wydatków konsumpcyjnych zachodzących w latach 2006-2014 w gospodarstwach domowych zamieszkałych na wsiach i w miastach przeprowadzono również przy założeniu, że ceny w 2014 roku kształtowały się tak jak te w 2006. W tabeli 4 przedstawiono wysokość wydatków konsumpcyjnych w 2014 roku w cenach z 2006 roku oraz stopę wzrostu wydatków na poszczególne dobra i usługi konsumpcyjne w ujęciu realnym w gospodarstwach domowych wiejskich i miejskich. Ponieważ w publikacji Głównego Urzędu Statystycznego dotyczącej cen w gospodarce narodowej nie podaje się wskaźników wzrostu cen dla kategorii „kieszonkowe” przyjęto, że wzrost cen w tej kategorii był równy inflacji mierzonej wskaźnikiem wzrostu cen towarów i usług konsumpcyjnych.

Uwzględniając zmiany cen poszczególnych towarów i usług konsumpcyjnych, które nastapily od roku 2006 do 2014, w badanym okresie w ujęciu realnym zmniejszyły się przeciętne wydatki na żywność i napoje bezalkoholowe w gospodarstwach domowych wiejskich (o 4,3\%), na napoje alkoholowe, wyroby tytoniowe i narkotyki zarówno w gospodarstwach domowych wiejskich (o 9,3\%), jak i miejskich (o 5,8\%) oraz na użytkowanie mieszkania i nośniki energii $\mathrm{w}$ gospodarstwach domowych miejskich (o $0,8 \%$ ). Jednocześnie największe wzrosty przeciętnych wydatków na osobę między rokiem 2006 a 2014 $\mathrm{w}$ ujęciu realnym odnotowano w przypadku wydatków na restauracje i hotele zarówno w gospodarstwach domowych wiejskich (o 165\%), jak i w miejskich (o 126,4\%) oraz na odzież i obuwie zarówno w gospodarstwach domowych na wsi (o 125,1\%), jak i w mieście (o 117\%).

Sprawdzono również, czy w latach 2006-2014 gospodarstwa miejskie i wiejskie upodobnily się do siebie pod względem struktury wydatków konsumpcyjnych. Wykorzystano w tym celu miarę zróżnicowania struktur opartą na metryce Braya-Curtisa opisaną wzorem: 
Tabela 4

Przeciętne miesięczne wydatki na poszczególne kategorie towarów i usług konsumpcyjnych na osobę w gospodarstwach domowych wiejskim i miejskim w 2014 roku w cenach bieżących z 2006 roku w zł oraz ich stopa wzrostu w latach 2006-2014

\begin{tabular}{|l|c|c|c|c|}
\hline \multirow{2}{*}{ Wydatki/wyszczególnienie } & \multicolumn{2}{|c|}{$\begin{array}{c}\text { Gospodarstwa } \\
\text { domowe wiejskie }\end{array}$} & \multicolumn{2}{c|}{$\begin{array}{c}\text { Gospodarstwa } \\
\text { domowe miejskie }\end{array}$} \\
\cline { 2 - 5 } & $\begin{array}{c}\text { Wydatki } \\
\text { w 2014 r. } \\
\text { w cenach } \\
\text { z 2006 r. }\end{array}$ & $\begin{array}{c}\text { Stopa } \\
\text { wzrostu } \\
2006-2014 \\
{[\%]}\end{array}$ & $\begin{array}{c}\text { Wydatki } \\
\text { w 2014 r. } \\
\text { w cenach } \\
\text { z 2006 r. }\end{array}$ & $\begin{array}{c}\text { Stopa } \\
\text { wzrostu } \\
2006-2014 \\
{[\%]}\end{array}$ \\
\hline Żywność i napoje bezalkoholowe & 184,23 & $-4,3$ & 208,82 & 0,4 \\
\hline $\begin{array}{l}\text { Napoje alkoholowe, wyroby tytoniowe } \\
\text { i narkotyki }\end{array}$ & 14,73 & $-9,3$ & 21,03 & $-5,8$ \\
\hline Odzież i obuwie & 70,81 & 125,1 & 98,98 & 117,0 \\
\hline $\begin{array}{l}\text { Użytkowanie mieszkania i nośniki } \\
\text { energii }\end{array}$ & 112,55 & 0,4 & 167,26 & $-0,8$ \\
\hline $\begin{array}{l}\text { Wyposażenie mieszkania i prowadzenie } \\
\text { gospodarstwa domowego }\end{array}$ & 38,74 & 25,6 & 52,34 & 23,5 \\
\hline Zdrowie & 33,21 & 17,9 & 50,54 & 20,9 \\
\hline Transport & 75,83 & 29,4 & 86,09 & 23,9 \\
\hline Łaczność & 47,05 & 67,0 & 68,97 & 54,3 \\
\hline Rekreacja i kultura & 45,23 & 47,1 & 78,30 & 16,5 \\
\hline Edukacja & 5,10 & $-10,1$ & 13,77 & 2,7 \\
\hline Restauracje i hotele & 19,50 & 165,0 & 43,37 & 126,4 \\
\hline Pozostałe towary i usługi & 39,77 & 45,5 & 64,76 & 45,1 \\
\hline Kieszonkowe & 16,20 & 104,1 & 12,08 & 27,2 \\
\hline
\end{tabular}

Źródło: Opracowanie własne na podstawie danych z tabel 1 oraz z 2.

$$
v_{1}=\frac{\sum_{j=1}^{m}\left|q_{1 j}-q_{2 j}\right|}{\sum_{j=1}^{m}\left|q_{1 j}+q_{2 j}\right|}
$$

gdzie:

$q_{1 j}$ - udział j-tego składnika w strukturze obiektu pierwszego,

$q_{2 j}$ - udział j-tego składnika w strukturze obiektu drugiego.

Miara ta przyjmuje wartości od 0 do 1, przy czym przyjmuje wartość 0 dla struktur identycznych i 1 dla struktur całkowicie niepodobnych [Kukuła 2014].

W tabeli 5 przedstawiono miarę zróżnicowania struktury wydatków na towary i usługi konsumpcyjne między gospodarstwami domowymi zamieszkałymi na wsi i w mieście. 


\section{Tabela 5}

Miara zróżnicowania wydatków na towary i usługi konsumpcyjne w wiejskich i miejskich gospodarstwach domowych

\begin{tabular}{|l|c|}
\hline Wyszczególnienie & $\begin{array}{c}\text { Miara zróżnicowania struktury wydatków konsumpcyjnych } \\
\text { między wiejskimi a miejskimi gospodarstwami domowymi }\end{array}$ \\
\hline W 2006 roku & 0,089 \\
\hline W 2014 roku & 0,079 \\
\hline W 2014 roku w cenach & 0,076 \\
z 2006 roku
\end{tabular}

Źródło: Opracowanie własne.

W latach 2006-2014 gospodarstwa domowe zamieszkałe na wsi i w mieście upodobniły się do siebie pod względem struktury wydatków konsumpcyjnych, o czym świadczy zmniejszenie się miary zróżnicowania struktur z 0,089 w 2006 roku do 0,076 w 2014 roku w cenach stałych i do 0,079 w cenach bieżących. Można również zauważyć, że zmiany cen towarów i usług konsumpcyjnych nie wpływają znacząco na zróżnicowanie struktury wydatków konsumpcyjnych między wiejskimi i miejskimi gospodarstwami domowymi. Zarówno w cenach stałych, jak i w cenach bieżących gospodarstwa domowe wiejskie i miejskie upodobniły się do siebie pod względem struktury wydatków konsumpcyjnych.

Upodabnianie się do siebie pod względem struktury wydatków konsumpcyjnych wiejskich i miejskich gospodarstw domowych może mieć związek również z faktem, że w gospodarstwach domowych wiejskich, o niższych początkowych poziomach dochodu do dyspozycji na osobę, występuje szybsze tempo ich wzrostu niż w gospodarstwach domowych miejskich [Utzig 2014].

\section{Podsumowanie}

Przeprowadzone badania pozwalają na sformułowanie następujących wniosków:

1. Zarówno w 2006, jak i w 2014 roku przeciętne wydatki na prawie wszystkie kategorie towarów i usług konsumpcyjnych były wyższe w gospodarstwach domowych miejskich niż w wiejskich.

2. Zarówno w gospodarstwach domowych wiejskich, jak i w miejskich największy udział w strukturze wydatków konsumpcyjnych miały wydatki na żywność i napoje bezalkoholowe oraz wydatki na użytkowanie mieszkania i nośniki energii.

3. Udział wydatków na żywność i napoje bezalkoholowe zmniejszył się w latach 2006-2014 zarówno w gospodarstwach domowych wiejskich, jak i miejskich, co świadczy o poprawie ich sytuacji finansowej. 
4. W okresie 2006-2014 największe wzrosty odnotowały ceny wyposażania mieszkania i nośników energii oraz napojów alkoholowych, wyrobów tytoniowych i narkotyków. Jednocześnie spadły ceny odzieży i obuwia oraz wydatków zaliczanych do kategorii łączność.

5. W latach 2006-2014 realnie zmniejszyły się przeciętne wydatki na żywność i napoje bezalkoholowe na osobę w gospodarstwach domowych wiejskich, na napoje alkoholowe, wyroby tytoniowe i narkotyki zarówno w gospodarstwach domowych wiejskich, jak i miejskich. Jednocześnie znacznie zwiększyły się w ujęciu realnym wydatki na restauracje i hotele oraz na odzież i obuwie zarówno w gospodarstwach domowych wiejskich, jak i miejskich, co jest pozytywnym zjawiskiem, gdyż gospodarstwa domowe przeznaczają coraz więcej na wydatki niezaspokajające najbardziej podstawowych potrzeb.

6. W latach 2006-2014 gospodarstwa domowe wiejskie upodobnily się do gospodarstw domowych miejskich pod względem struktury wydatków konsumpcyjnych w ujęciu nominalnym i realnym.

\section{Literatura}

Budżety gospodarstw domowych w 2006 r., Główny Urząd Statystyczny, Warszawa 2007.

Budżety gospodarstw domowych w 2014 r., Główny Urząd Statystyczny, Warszawa 2015.

Ceny w gospodarce narodowej w 2012 r., Główny Urząd Statystyczny w Opolu, Warszawa 2013.

Ceny w gospodarce narodowej w 2014 r., Główny Urząd Statystyczny w Opolu, Warszawa 2015.

GAŁAZZKA M., 2012: Wpływ społeczno-demograficznych determinantów ksztaltowania się wydatków na żywność i napoje bezalkoholowe w gospodarstwach domowych w Polsce, Roczniki Ekonomiczne Kujawsko-Pomorskiej Szkoły Wyższej w Bydgoszczy 5, s. $223-239$.

GRUDA M., REMBISZ W., 2013: Tendencje zmian w światowej, unijnej i polskiej produkcji $i$ konsumpcji żywności do 2030/2050 roku, IERiGŻ PIB, Warszawa.

GUTKOWSKA K., PIEKUT M., 2014: Konsumpcja $w$ wiejskich gospodarstwach domowych, Wieś i Rolnictwo 4(165), s. 159-178.

KOZERA A., STANISŁAWSKA J., WYSOCKI F., 2014: Sytuacja finansowa gospodarstw domowych zamieszkujacych obszary wiejskie $w$ Polsce po wstapieniu Polski do Unii Europejskiej, Roczniki Naukowe Ekonomii Rolnictwa i Rozwoju Obszarów Wiejskich 101, 2, s. 91-101.

KUKUŁA K., 2014: Statystyczne podejście do badań dynamiki struktur ekonomicznych, Marketing i Rynek 2, s. 84-91.

PIEKUT M., 2013: Konsumpcja polskich gospodarstw domowych na tle krajów europejskich, Problemy Zarządzania 1(40), 1, s. 23-39.

PODOGRODZKA M., 2011: Zmiany demograficznych struktur ludności jako determinanty poziomu wydatków konsumpcyjnych, Zeszyty Naukowe Uniwersytetu Rzeszowskiego 19 , s. 310-324. 
RADZIUKIEWICZ M., 2012: Zmiany sytuacji dochodowej a wydatki na ustugi w polskich gospodarstwach domowych, Konsumpcja i Rozwój 1(2), s. 101-116.

UTZIG M., 2014: Konwergencja dochodowa ludności wiejskiej i miejskiej w Polsce, Roczniki Naukowe Ekonomii Rolnictwa i Rozwoju Obszarów Wiejskich 101, 4, s. 144-152.

UTZIG M., 2015a: Przemiany w strukturze wydatków konsumpcyjnych gospodarstw domowych w Polsce, Konsumpcja i Rozwój 3(12), s. 29-40.

UTZIG M., 2015b: Wydatki konsumpcyjne wiejskich i miejskich gospodarstw domowych a zmiany ich dochodów, Roczniki Naukowe SERiA XVII, 4, s. 330-335.

ZALEGA T., 2011: Wptyw kryzysu na postawy i zachowania gospodarstw domowych wysokodochodowych, Nierówności Społeczne a Wzrost Gospodarczy 18, s. 468-485.

ZALEGA T., 2013: Nowe trendy $w$ zachowaniach konsumpcyjnych miejskich gospodarstw domowych w okresie kryzysu, Marketing i Rynek 8, s. 24-31.

\section{Abstrakt}

W opracowaniu przedstawiono wydatki na towary i usługi konsumpcyjne oraz ich zmiany w wiejskich i miejskich gospodarstwach domowych w latach 2006-2014. Przeanalizowano również zmiany cen wydatków konsumpcyjnych w tym okresie z wykorzystaniem danych Głównego Urzędu Statystycznego.

W okresie 2006-2014 udział wydatków na odzież i obuwie oraz na hotele i restauracje zwiększył się $\mathrm{w}$ ujęciu realnym zarówno w wiejskich, jak i miejskich gospodarstwach domowych, co może być ocenione pozytywnie. Zróżnicowanie struktury wydatków konsumpcyjnych między wiejskimi a miejskimi gospodarstwami domowymi zmniejszyło się w latach 2006-2014.

Slowa kluczowe: wiejskie i miejskie gospodarstwa domowe, struktura wydatków konsumpcyjnych, ceny dóbr i usług konsumpcyjnych

\section{Rural and urban households' expenditures on consumer goods and services and its prices}

\section{Abstract}

The paper presents rural and urban households' expenditures on consumption goods and services and their change in years 2006-2014. Consumption expenditure price changes in this span was also analysed with the use of Central Statistical Office's data.

In the analysed years the share of expenditure on clothing and footwear and on restaurants and hotels increased in real terms in both rural and urban house holds, what can be evaluated positively. Consumption expenditure structure 
differences between urban and rural households decreased between 2006 and 2014.

Key words: rural and urban households, consumption pattern, consumer goods and services prices 